\title{
L'évangile et l'outil : le changement technique dans un village indien du Mexique au XVIe siècle
}

Jean-Pierre Berthe

\section{(2) OpenEdition}

\section{Édition électronique}

URL : https://journals.openedition.org/tc/818

DOI : $10.4000 /$ tc. 818

ISSN : 1952-420X

Éditeur

Éditions de l'EHESS

\section{Édition imprimée}

Date de publication : 1 octobre 1988

ISSN : 0248-6016

\section{Référence électronique}

Jean-Pierre Berthe, «L'évangile et l'outil : le changement technique dans un village indien du Mexique au XVle siècle», Techniques \& Culture [En ligne], 11 | 1988, mis en ligne le 16 janvier 2006, consulté le 29 septembre 2022. URL : http://journals.openedition.org/tc/818; DOI : https://doi.org/10.4000/tc. 818

Ce document a été généré automatiquement le 29 septembre 2022.

Tous droits réservés 
L'évangile et l'outil : le changement technique dans un village indien $\mathrm{du}$ Mexique au XVIe siècle

Jean-Pierre Berthe 